\title{
Investor protections and economic growth
}

\author{
Jamal Ibrahim Haidar $*, 1$ \\ The World Bank 2121 Pennsylvania Ave., NW Washington, DC 20433, United States
}

\section{A R T I C L E I N F O}

\section{Article history:}

Received 4 January 2008

Received in revised form 3 December 2008

Accepted 8 December 2008

Available online 14 December 2008

\begin{abstract}
A B S T R A C T
Using objective measures of investor protections in 170 countries, I establish that the level of investor protection matters for cross-country differences in GDP growth: countries with stronger protections tend to grow faster than those with poor investor protections.
\end{abstract}

(C) 2008 Elsevier B.V. All rights reserved.

\section{F43 \\ G15 \\ G38 \\ L26 \\ L51 \\ 011 \\ 043}

Keywords:

Corporate governance

Investor protection

Self-dealing

Growth

JEL classifications:

\section{Introduction}

Where expropriation of minority investors is curbed, equity investment is higher and ownership concentration is lower. ${ }^{2}$ This means that where laws fail to stop self-dealing, ownership concentration is higher because having a majority stake is the only way to prevent being cheated. I take the corporate governance research further by studying the relationship between investor protections and economic growth.

I use a new objective country-level data set on legal protection of minority shareholders against expropriation by corporate insiderstermed the Investor Protection Index. The analysis focuses on a particular type of corporate governance: investor protections. The results show that the level of investor protection matters for cross-country differences in economic growth: countries with strong investor protection tend to grow faster than countries with poor investor protection.

\footnotetext{
* Tel.: +1 202473 3219; fax: +1 2024735758.

E-mail address: JHaidar@worldbank.org.

1 The author would like to thank Mohammad Amin, Allen Dennis, Simeon Djankov, and Facundo Martin for their useful comments.

2 Shleifer and Wolfenzon (2002) and Black (2001).
}

\section{Literature review: Investor protection and economic growth}

A strain of literature studies the relationship between "corporate governance" and economic growth. Corporate governance is the set of processes, customs, policies, laws and institutions affecting the way people direct, administer, or control a corporation. A rationale for the positive effects of corporate governance on aggregate growth lies on the fact that corporate sector makes up a sizeable share of the economy. If this sector is prosperous and is robust to external economic shocks, then it is likely that the economy will have a relatively high growth rate.

The theoretical result of Castro et al. (2004) is that the relation between investor protection and economic growth depends on two opposing effects. On one hand, an improvement in investor protection leads to better risk sharing, which implies a larger demand for capital. This "demand" effect supports a positive association between investor protection and growth. On the other hand, the "supply" effect works in the opposite direction. Better investor protection implies higher interest rate due to a shift of demand schedule. A higher interest rate translates into lower income for entrepreneurs which are the young generation, resulting in lower supply of capital in the following period. Empirically, La Porta et al. (1998) find that the "supply" effect is weaker than the "demand" effect in countries with fewer restrictions on capital flows. 
Table 1

Summary statistics

\begin{tabular}{lcrccc}
\hline Variable & No. obs & Mean & Std. dev. & Min & Max \\
\hline Investor Protection Index & 174 & 5.03 & 1.52 & 0 & 9.7 \\
Disclosure index & 174 & 4.93 & 2.61 & 0 & 10 \\
Director liability index & 174 & 4.53 & 2.38 & 0 & 9 \\
Shareholder suit index & 174 & 5.63 & 2.13 & 0 & 10 \\
Real growth rate of GDP per capita & 170 & 1.54 & 2.22 & -3.94 & 10.92 \\
Investment rate (\% GDP) & 172 & 13.80 & 7.29 & 0 & 40.31 \\
Log GDP per capita 1965 & 99 & 7.94 & 1.03 & 5.81 & 9.79 \\
Log GDP per capita 1980 & 156 & 8.32 & 1.13 & 5.99 & 10.86 \\
Average years of schooling 1965 & 99 & 3.70 & 2.50 & 0.17 & 9.74 \\
Average years of schooling 1980 & 106 & 4.77 & 2.80 & 0.26 & 11.87 \\
Economic stability & 127 & 36.15 & 6.29 & 6.5 & 48 \\
Political stability & 127 & 67.88 & 12.51 & 31.5 & 93.5 \\
Financial stability & 127 & 37.09 & 6.16 & 9.5 & 48.5 \\
Dummy for high-income economies & 195 & 0.18 & 0.39 & 0 & 1 \\
Dummy for common law & 195 & 0.24 & 0.43 & 0 & 1 \\
\hline
\end{tabular}

Djankov et al. (2008) presented a new measure of legal protection of minority shareholders against expropriation by corporate insiders: the anti-self-dealing index. The authors calculated an index for 72 countries based on legal rules prevailing in 2003, and focused on private enforcement mechanisms, such as disclosure, approval, and litigation, that govern a specific self-dealing transaction. This theoretically grounded index predicted a variety of stock market outcomes, and generally worked better than the previously introduced index of anti-director rights constructed by La Porta, Lopez-deSilanes, Shleifer, and Vishny $(1997,1998)$. Specifically, the index is sharply higher in common law countries than in French civil law countries. Statistically, the index is also a significant and economic strong predictor of a variety of measures of stock market development across countries. These results showed that theoretically grounded measures of investor protection are closely tied to financial development. The paper delineated the implications of these findings in three areas: the measurement of shareholder protection, the interpretation of legal origin, and the design of regulatory strategies.

Djankov et al. (2008) paper showed the relation between five proxies for the development of stock markets and the anti-director rights index, which they created. The index is unrelated to the control premium but otherwise has a large effect on the development of stock markets. For example, a two standard-deviation increase in the revised anti-director rights index is associated with an increase in the stock market-capitalization-to-GDP ratio of 23 percentage points (sample mean of 59\%), a 92\% increase in the number of domestic firms per million inhabitants, an increase of 1.5 percentage points in the IPOs-to-GDP ratio (sample mean of 3\%), and a reduction of seven percentage points in ownership concentration (sample mean of $47 \%$ ).

\section{Data}

I obtained data from the World Bank Doing Business database, which is available at www.doingbusiness.org. The data is based on the investor protections index (IPI) of doingbusiness. The IPI is based on Djankov et al. (2008) but has been updated by the World Bank. The IPI measures the strength of minority shareholder protections against directors' misuse of corporate assets for personal gain. The indicators distinguish 3 dimensions of investor protection: transparency of related-party transactions (extent of disclosure index), liability for self-dealing (extent of director liability index), and shareholders' ability to sue officers and directors for misconduct (ease of shareholder suits index). The data come from a survey of corporate lawyers and are based on securities regulations, company laws and court rules of evidence. Unlike the perception-based index of anti-director rights created by La Porta et al. (1997), the Doing Business investor protections index provides objective measures of investor protections regulations and their enforcement across 170 countries. While La
Porta's investor protections index was based on ad-hoc collection of variables meant to capture the stance of corporate law toward shareholder protection, the IPI considered in this paper focuses on how regulations address directors' self dealing to determine the strengths of minority shareholder protections against the misuse of corporate assets by directors for their personal gain. The index ranges from 0 to 10, with higher values indicating better investor protection (Table 1).

Data on real GDP per capita and investment share of GDP come from Penn World Tables. Human Capital is measured as average years of schooling of population over 15 years of age. This variable is provided for every five-year interval for the years 1960-2000 in Barro-Lee data set available at http://www.cid.harvard.edu/ciddata/ ciddata.html. The dummy for high-income countries has a value of 1 if a country belongs to a "High-Income: OECD" or "High Income: NonOECD" group classified by the World Bank; 0 otherwise. Legal system refers to either common or civil law origin as mentioned by La Porta et al. (1998). Economic, financial, and political stability indices are extracted from the Economic Risk Rating assessed by the International Country Risk Guide (ICRG)

\section{Discussion of results}

\subsection{Basic results}

In this section, I examine whether the degree of investor protection is important in explaining cross-country differences in economic growth. I question whether investor protection is associated with long-term economic growth. Then, I test the relation between investor protection and growth for the cross section of countries using the following model:

Growth $=\alpha+\beta \cdot \operatorname{IPI}+\gamma \cdot \operatorname{Ln}(\mathrm{GDPpc} 65)+\delta \cdot I+\lambda \cdot H+\varepsilon$

where Growth is an average economic growth over the period 1980-2004; IPI is the Investor Protection Index; GDPpc65 is the log of GDP per capita in 1965 (as a measure of the scope for catch-up); I denotes an average investment rate over the period 1980-2004; $H$ represents initial level of human capital measured by years of schooling completed by 1965 . Column 1 of Table 2 presents baseline results from a standard growth regression without the IPI in the set of explanatory variables. Reassuringly, all of the measures of the growth factors have the expected signs and are strongly correlated to the average growth rate. When I add the index of investor protection (column 2) as another independent variable, its coefficient becomes positive and highly significant at $1 \%$ level, while the results on the three growth factors remain robust. Apparently, investor protection is another factor that may explain cross-country differences in economic growth. In Column 3, I include a dummy for high-income country and an interaction between this dummy and the IPI to test whether the effects of investor protection differ between high- and low-income economies. ${ }^{3}$ Interestingly, the negative coefficient on the interaction term suggests that the effect of investor protection on economic growth is smaller for highincome economies. In other words, the level of investor protection matters more for poor countries than it does for rich countries in term of growth induction. This finding is quite plausible given that poorer countries are more in need of external finance to stimulate growth, and one of the prerequisites for drawing on external finance is to make both local and foreign investors confident that they are sufficiently protected for their capital invested. As a result, holding everything else the same, poor countries that have established

\footnotetext{
${ }^{3}$ To define a country as a high- or low-income economy, we refer to the World Bank's list of economies which provides classification of countries by income group according to the World Bank's definition.
} 
Table 2

Investor protection and growth

\begin{tabular}{llll}
\hline \multicolumn{4}{l}{ Dependent variable: average growth rate of GDP per capita, 1980-2004 } \\
\hline & $(1)$ & $(2)$ & $(3)$ \\
\hline $\begin{array}{l}\text { Investment share of GDP, average } \\
\text { 1980-2004 }\end{array}$ & $0.109^{* * *}(5.35)$ & $0.104^{* * *}(5.01)$ & $0.088^{* * *}$ \\
Log GDP per capita, 1965 & $-1.052^{* * *}$ & $-0.968^{* * *}$ & $(4.94)$ \\
& $(4.69)$ & $(4.27)$ & $\left(4.052^{* * *}\right.$ \\
Human capital, 1965 & $0.322^{* * *}$ & $0.230^{* *}(2.39)$ & $0.180^{* *}(2.00)$ \\
& $(3.34)$ & & \\
Investor protection & & $0.263^{* * *}(3.04)$ & $0.457^{* * *}(3.06)$ \\
Dummy for high-income country & & & $2.999^{* * *}$ \\
& & & $(2.96)$ \\
Dummy for high-income*investor & & $-0.396^{* *}$ \\
protection & $7.002^{* * *}(4.43)$ & $5.327^{* * *}(3.12)$ & $8.240^{* * *}$ \\
Constant & & & $(3.69)$ \\
& 76 & 76 & 76 \\
Observations & 0.40 & 0.46 & 0.51 \\
$R$-squared & & & \\
\hline
\end{tabular}

Robust $t$-statistics in parentheses.

******, significant at $5 \%$ and $1 \%$ level, respectively.

stronger protection of investors are likely to be more prosperous over time.

\subsection{Robustness checks}

Next I check robustness of the above results. First, I replace the initial log of GDP per capita and human capital in 1965, with their values in 1980 (Table 3, column 1). The signs and significance of the coefficients remain unchanged from above (Table 3, column 2). Second, I replace the IPI with its sub-components-disclosure index, director liability index, and shareholder suit index-to investigate which aspect(s) of the investor protection is driving the positive effects on growth (Table 3, column 2). I find that the disclosure index is the only significant component, while the extent of director liability and the ease of shareholder suits do not seem to matter for economic growth. The results on these three sub indices hold when I introduce them one by one into the regression. The implication is that, relative to other corporate governance aspects, a country needs to place greater emphasis on disclosure of information and transparency of local firms in order to attract external finance and to ensure that firm's resources are used for productive investment.

Third, I introduce three more variables-namely, indices for economic stability, political stability, and financial stability-into the regression as additional controls for economic growth (column 3 ). Again, the main results do not differ much, except for the human capital measure that becomes insignificant. The positive effect of investor protection remains robust. Political stability and financial stability are both positively correlated with the rate of growth, while the coefficient on the economic stability index is not statistically different from zero.

Forth, instead of comparing the effects of investor protection between rich and poor countries like in regression 3 of Table 2, I now investigate whether there are differential effects of investor protection on growth between countries with different legal systems (Table 3, column 4). Pioneered by La Porta et al. (1998), a number of studies stress the importance of the legal system in influencing the quality of corporate governance, which is in turn a key ingredient for sustainable economic growth. I simply divide the legal origin into common and civil laws and create a dummy variable that indicates a common law origin. The coefficient on the common-law dummy is negative and significant at $5 \%$ level, implying that countries whose legal systems are based on common law generally have lower rate of growth. However, the positive coefficients on both the IPI and the interaction term suggests that, holding everything else constant, both common- and civil-law-origin countries can stimulate growth by strengthening its investor protection.

\section{Conclusion}

This paper studies the relationship between investor protection and economic growth using a new measure of legal protection of minority shareholders against expropriation by corporate insiders-termed Investor Protection Index-for more than 170 countries around the world. I find that the level of investor protection matters for crosscountry differences in economic growth: countries with strong protection tend to grow faster than those with poor investor protection. The results from sensitivity analysis reinforce the importance of investor protection, especially in the disclosure and transparency dimension, for long-term economic growth for all countries with differing economic and legal backgrounds.

However, there are some caveats in generalizing the results from this study. First, a potential endogeneity problem between growth and investor protection is not directly addressed in this paper. Averaging the growth rates over a long period of time may help reduce the feedback effect from economic growth to improvement in investor protection, but only partially. One might need to find a way to cope with the problem of identification in order to correctly determine the direction of causality. Second, investor protection is only one aspect of corporate governance. Besides shareholder rights, corporate governance mechanisms also include board structure, audit committee, compensation committees, balance of power between control and management, and various incentive alignment programs such as employee stock options. Countries with weak legal protection of minority investors may have other ways to improve overall corporate governance and hence strengthen the corporate sector of the countries which ultimately lead to superior economic performance and sustainable growth. Further research can address this matter as well as whether creditor protections are equally relevant for economic growth.

Table 3

Robustness checks

\begin{tabular}{|c|c|c|c|c|}
\hline \multicolumn{5}{|c|}{ Dependent variable: average growth rate of GDP per capita, 1980-2004 } \\
\hline & (1) & $(2)$ & (3) & (4) \\
\hline $\begin{array}{l}\text { Investment share of GDP, } \\
\text { average 1980-2004 }\end{array}$ & $\begin{array}{l}0.138^{* * *} \\
(4.70)\end{array}$ & $\begin{array}{l}0.118^{* * * *} \\
(5.07)\end{array}$ & $\begin{array}{l}0.114^{* * *} \\
(3.83)\end{array}$ & $\begin{array}{l}0.113^{* * * *} \\
(4.53)\end{array}$ \\
\hline Log GDP per capita, 1980 & $\begin{array}{l}-0.934^{* * *} \\
(3.30)\end{array}$ & $\begin{array}{l}-0.940 * * * \\
(3.65)\end{array}$ & $\begin{array}{l}-1.170^{* * * *} \\
(4.12)\end{array}$ & $\begin{array}{l}-1.341^{* * *} \\
(4.69)\end{array}$ \\
\hline Human capital, 1980 & $\begin{array}{l}0.179 * * \\
(2.00)\end{array}$ & $\begin{array}{l}0.225^{* *} \\
(2.35)\end{array}$ & $\begin{array}{l}0.140 \\
(1.62)\end{array}$ & $\begin{array}{l}0.135 \\
(1.60)\end{array}$ \\
\hline Investor protection index & $\begin{array}{l}0.252^{* *} \\
(2.48)\end{array}$ & & $\begin{array}{l}0.242 * * \\
(2.84)\end{array}$ & $\begin{array}{r}0.216^{*} \\
(1.76)\end{array}$ \\
\hline Disclosure index & & $\begin{array}{l}0.226 * * * \\
(3.95)\end{array}$ & & \\
\hline Director liability index & & $\begin{array}{l}-0.049 \\
(0.78)\end{array}$ & & \\
\hline Shareholder suit index & & $0.015(0.17)$ & & \\
\hline Economic stability & & & $\begin{array}{l}-0.068 \\
(1.60)\end{array}$ & $\begin{array}{l}-0.070 \\
(1.64)\end{array}$ \\
\hline Political stability & & & $\begin{array}{l}0.043^{* *} \\
(2.40)\end{array}$ & $\begin{array}{l}0.047 * * * \\
(2.73)\end{array}$ \\
\hline Financial stability & & & $\begin{array}{l}0.107 * * * \\
(2.88)\end{array}$ & $\begin{array}{l}0.108^{* * *} \\
(3.00)\end{array}$ \\
\hline Dummy for common law & & & & $\begin{array}{l}-2.352^{* *} \\
(2.15)\end{array}$ \\
\hline $\begin{array}{l}\text { Dummy for common } \\
\text { law*investor protection }\end{array}$ & & & & $\begin{array}{l}0.288^{*} \\
(1.68)\end{array}$ \\
\hline Constant & $\begin{array}{l}4.944^{* *} \\
(2.54)\end{array}$ & $\begin{array}{l}5.347 * * * \\
(2.89)\end{array}$ & $\begin{array}{l}3.122 * \\
(1.67)\end{array}$ & $\begin{array}{l}4.632^{* * *} \\
(2.35)\end{array}$ \\
\hline Observations & 97 & 97 & 97 & 97 \\
\hline$R$-squared & 0.41 & 0.47 & 0.53 & 0.57 \\
\hline
\end{tabular}

Robust $t$-statistics in parentheses.

$* * * * * *$ significant at $10 \%, 5 \%$, and $1 \%$ level, respectively. 


\section{References}

Black, Bernard, 2001. The legal and institutional preconditions for strong securities markets. UCLA Law Review 48 (3), 781-855.

Shleifer, A., Wolfenzon, D., 2002. Investor protection and equity markets. Journal of Financial Economics 66, 3-27.

Castro, R., Clementi, G.L., MacDonald, G., 2004. Investor protection, optimal incentives, and economic growth. The Quarterly Journal of Economics 119, 1131-1175.
La Porta, R., Lopez-de-Silanes, F., Shleifer, A., Vishny, R., 1997. Legal determinants of external finance. Journal of Finance 52, 1131-1150.

La Porta, R., Lopez-de-Silanes, F., Shleifer, A., Vishny, R., 1998. Law and finance. Journal of Political Economy 106 (6), 1113-1155.

Djankov, S., La Porta, R., Lopez-de-Silanes, F., Shleifer, A., 2008. The law and economics of self-dealing. Journal of Financial Economics 88 (3), 430-466. 